\title{
ANÁlISE DE COMO É POSSÍVEL REALIZAR A PENHORA DE PRECATÓRIOS
}

\author{
ANALYSIS OF HOW IS POSSIBLE TO DO THE ATTACHMENT OF THE \\ PUBLIC GARNISHMENT
}

\author{
Álisson Barbalho Marangôni Correia ${ }^{1}$ \\ Pedro Henrique Moreira Simões ${ }^{2}$
}

\begin{abstract}
Resumo: O presente artigo tem por objetivo analisar como é possível realizar a penhora de créditos de precatório, porquanto a demora e a baixa efetividade no adimplemento das obrigações trazidas ao juízo têm feito com que os agentes do processo (juízes, advogados, promotores) reflitam sobre boas práticas, procedimentos a mitigarem os problemas jurisdicionais. Para tanto, se fez necessário um levantamento bibliográfico e documental para identificar os fundamentos teóricos que norteiam as execuções em geral, os créditos de precatório e como realizar a penhora de tais créditos, evidenciando o caráter qualitativo da pesquisa. Ademais, este estudo possui um objetivo exploratório, em virtude de haver poucas obras tratando dessa temática, em que pese sua relevância. Outrossim, o delineamento da pesquisa foi de um estudo de caso, haja vista o recorte metodológico adotado para estudar como a Resolução do CNJ n. 303, de 18 de dezembro de 2019, disciplina a matéria. Por fim, um dos principais resultados constatados foi que essa resolução estabeleceu que as regras da cessão de crédito serão aplicáveis naquilo que forem possíveis. Ademais, há a necessidade de averbação desse ato no processo de pagamento do precatório para que na última fase seja disponibilizado esse crédito ao juízo e, então, o credor seja pago.
\end{abstract}

PALAVRAS-CHAVE: Processo civil. Tutela executiva. Penhora de Precatório

\begin{abstract}
This article has the goal to analyze how is possible to do the attachment of the public garnishment, because the delay and the low effectiveness of the performance of the obligations brought to the judge have made the agents of the procedure (judges, lawyers, prosecutors) think about practices of public administrations, procedures to mitigate the jurisdictional problems. Therefore, it was needed to a bibliographical and documental research to identify the fundaments that guide the enforcement in general, the garnishment credits, and how to do the attachment of those credits, highlighting the qualitative character of this study. In addition, this paper has an exploratory goal, because there are a few papers about this theme, however its relevance. Thus, the design of the research was a study of case, considering the methodological cut to study how the Resolution of CNJ (sic) n. 303, of December 18 of 2019, discipline the matter. Ultimately, one of its main results are that this resolution established that the rules of the credit cession are used in the measure of the possibility. Furthermore, there is the need of endorsing the act in the procedure of public garnishment, in order to pay it at the last phase and to make it available to the judge and then, the payment of the creditor.
\end{abstract}

KEYWORDS: Procedure Code. Enforcement. Attachment of the Public Garnishment.

Advogado, especialista em Direito Público Aplicado pela Escola Brasileira de Direito (EBRADI) e Centro Universitário UNA, pesquisador do grupo de pesquisa ProLaw-Lab - precedentes e direitos humanos, da Universidade de Brasília (UnB) - alissonbmcorreia@gmail.com

2 Procurador do Estado de Rondônia. Mestrando em Direito pela Faculdade Autônoma de Direito de São Paulo (FADISP) e professor da União das Escolas Superiores de Rondônia - Faculdade Interamericana de Porto Velho (UNIRON) - pedrosimoes@yahoo.com 


\section{Introdução}

É sabido que a tutela executória é a fase do processo responsável por concretizar os direitos reconhecidos na decisão judicial, sobretudo quando as decisões forem condenatórias ou constitutivas. Nessa senda, o Código de Processo Civil de 2015 (CPC/2015) prevê técnicas de execução que envolvem a entrega de coisa certa ou incerta, o cumprimento da obrigação de fazer ou de não fazer bem como o pagamento de quantia certa.

Vale salientar que essa última técnica pode substituir as anteriores como forma de reparação caso aquelas não tenham sido cumpridas. Consequentemente, o presente artigo se mostra relevante a essa última técnica, pois o objeto da pesquisa envolve o procedimento de penhora de créditos de precatório.

Outrossim, destaca-se que o códex processual vigente é aplicado subsidiariamente nas execuções fiscais, nas trabalhistas e nas dos juizados especiais. Consequentemente, o estudo desse meio sub-rogatório se mostra importante para a tutela executiva de um modo geral, notadamente porque o exequente expropriará os bens suficientes para satisfazer o seu crédito

Nesse contexto, levantou-se a seguinte problemática: Como é possível realizar a penhora de créditos de precatório?

Com escopo de responder essa problemática definiu-se o seguinte objetivo geral: analisar como é possível realizar a penhora de créditos de precatório. Para tanto, os objetivos específicos foram: (I) levantar os institutos que orientam a tutela executória; (II) levantar as normas que orientam a penhora; (III) verificar as disposições que norteiam o pagamento de precatórios; (IV) construir um marco teórico, estabelecendo as premissas gerais; (V) aplicar o método-hipotético dedutivo na análise de como é possível realizar a penhora de créditos de precatório segundo a Resolução do CNJ n. 303, de 18 de dezembro de 2019.

Outrossim, com o objetivo de nortear a pesquisa desenvolvida levantou-se as seguintes hipóteses: a penhora de créditos de precatório encontra fundamento jurídico no inciso XIII do artigo 835 do CPC/2015 ou considerando que o crédito de precatório será pago em dinheiro (evento futuro certo), a sua penhora se daria com fundamento no inciso I do artigo 835 do $\mathrm{CPC} / 2015$.

Em relação aos aspectos metodológicos aplicados, destaca-se que a pesquisa desenvolvida é um estudo de caso, com um objetivo exploratório. Assim, foi necessário realizar um corte metodológico para que seja levado em consideração os fatores diretos e indiretos que influenciam a pesquisa. 
Ademais, foi realizado um levantamento bibliográfico e documental sobre execução, precatório e sobre a penhora com o objetivo de estabelecer as premissas gerais da pesquisa, as quais constituem o seu marco teórico. A partir das premissas gerais aduzidas nesse marco teórico foi aplicado o método hipotético-dedutivo para analisar como é possível realizar a penhora de créditos de precatório segundo a Resolução do CNJ n. 303, de 18 de dezembro de 2019.

Para tanto, o desenvolvimento este artigo foi organizado em três seções: na primeira será abordado de modo geral o conjunto de princípios, institutos, que norteiam a tutela executiva prevista no Código de Processo Civil. Na segunda, será abordado sobre a penhora, com ênfase as suas disposições gerais. Já na terceira será abordado sobre os precatórios com ênfase no procedimento de penhora de créditos de precatório, destacando-se os seus aspectos procedimentais.

Pelo exposto, é possível constatar como principais resultados que a Resolução do CNJ n. 303, de 18 de dezembro de 2019 estabelece que o procedimento da penhora aplicará naquilo que for possível o procedimento de cessão de crédito, notadamente pela necessidade de averbação do ato nos registros junto a Presidência do Tribunal. Ademais, a penhora de precatório é examinado pelo juízo da fazenda pública, com vista a adequar a extensão do cumprimento da ordem de penhora, ante a existência de questões de ordem pública, como a incidência de tributos, pagamento de honorários advocatícios.

\section{Abordagem geral sobre a tutela executiva à luz do novo código de processo civil atual}

É sabido que o CPC/2015, em seu livro II, dispõe normas gerais em matéria de tutela executória, que age supletivamente para integrar eventual lacuna nas leis especiais. Nesse sentido, "a tutela jurisdicional executiva consiste na prática de atos jurisdicionais tendentes à realização material do direito atual ou potencialmente violado" (MEDINA, 2017, p.739), fundado em um título judicial ou extrajudicial.

Essa atividade processual tem a finalidade de satisfazer o direito do credor a compelir o devedor a adimplir sua obrigação, seja de pagar quantia certa, de entregar coisa, de fazer ou de não fazer (CÂMARA, 2015). Para isso, o exequente, no momento de ajuizar a ação, precisa apresentar junto à petição inicial um dos títulos executivos previsto no artigo 784 do $\mathrm{CPC} / 2015$.

Assim, o CPC/2015, como norma de aplicação subsidiária, previu diversos instrumentos sub-rogatórios e coercitivos para que ocorra o adimplemento da obrigação exequenda. 


\subsection{Requisitos essenciais para o ajuizamento da execução:}

É sabido que para a petição inicial romper a inércia do Estado-juiz se faz necessário que os requisitos processuais genéricos e específicos, caso existam, sejam preenchidos (MONTENEGRO FILHO, 2016). Nesse sentido, o livro de execução do CPC/2015 prevê dois requisitos para se ajuizar qualquer execução: o título executivo e o inadimplemento do devedor.

\subsubsection{O título executivo}

Título executivo pode ser conceituado como sendo o ato jurídico dotado de eficácia executiva. Dessa forma, para que haja a responsabilização patrimonial do devedor por intermédio de tutela executiva a presença desse documento é uma condição essencial ao interesse de agir (CÂMARA, 2015).

É preciso pontuar que tanto o título executivo judicial quanto o extrajudicial precisam estar previstos em lei. Isso ocorre porque no ordenamento jurídico brasileiro impera a taxatividade dos títulos executivos, ou seja, o CPC/2015 traz um rol taxativo de hipóteses nos artigos 784 e 515 .

Importa ressalvar que Lourenço (2017) sustenta o entendimento minoritário na literatura que o inciso I do artigo 515 do CPC/2015 prevê a tipicidade do título executivo, de modo que não se falaria em uma necessidade de previsão legal, mas de características que se moldam a norma.

Superada a discussão acerca da taxatividade ou tipicidade dos títulos executivos, verifica-se que o título executivo é um pressuposto processual de validade da tutela executória. Consequentemente, caso a ação seja ajuizada sem que haja um título executivo correspondente a uma obrigação certa, líquida e exigível, opera-se o brocardo Nulla executio sine título, nestes termos dispõe o artigo 803 do CPC/2015:

Art. 803. É nula a execução se: I - o título executivo extrajudicial não corresponder à obrigação certa, líquida e exigível;

Donizetti (2016), comparando a redação atual dessa norma com a do CPC/73, observa que a expressão título líquido, certo e exigível mudou para obrigação certa, líquida e exigível, em virtude de uma mudança conceitual de que a certeza é um pressuposto da obrigação líquida, que, no direito obrigacional, é conceituada como: 
É aquela certa quanto à existência, e determinada quanto ao objeto e valor. Nela se encontram especificadas, de modo expresso, a quantidade, a qualidade e a natureza do objeto devido. O inadimplemento de obrigação positiva e líquida no exato vencimento constitui o devedor em mora automaticamente (mora exre), nos termos do art. 397, caput, do Código Civil em vigor. (TARTUCE, 2016, p. 100)

Consequentemente, é possível inferir que a obrigação ilíquida embora possua certeza quanto a existência de uma obrigação, há uma indeterminação quanto ao objeto e o seu valor. Em razão disso, se faz necessário a realização de um procedimento de liquidação para que haja o seu cumprimento.

Já sob a ótica processual, esses conceitos são aplicados da seguinte forma:

A obrigação cuja execução se postula deve ser certa. Significa isto dizer que só se pode promover a execução se todos os seus elementos constitutivos (credor, devedor e objeto) estiverem precisamente indicados. Caso o bem jurídico que constitui o objeto da obrigação seja um bem fungível, que precisa ser quantificado, será exigida não só a certeza, mas também a liquidez, ou seja, a precisa determinação da quantidade devida. Não se considera ausente esta característica da obrigação exequenda, porém, se sua apuração depender apenas de simples operações aritméticas (art. 786, parágrafo único). Por fim, a obrigação exequenda deve ser exigível. A obrigação é exigível quando seu cumprimento não está sujeito a termo, condição ou algum outro elemento que não lhe seja essencial (como, por exemplo, um encargo). (CÂMARA, 2015, p.322) [grifo nosso]

Por fim, é preciso pontuar que o código processual prevê que o adimplemento das obrigações levará em consideração a repercussão monetária do lapso temporal, isto é, a incidência de juros e atualização monetária.

\subsubsection{O inadimplemento do devedor}

O inadimplemento do devedor é um pressuposto processual que confere interesse de agir da tutela executiva (MARINONI; ARENHART; MITIDIERO, 2016). Pois, não basta ao exequente ser credor de uma obrigação certa, líquida e exigível, representada por um título executivo é preciso também que se enquadre nas regras do inadimplemento previstas no código civilista (CÂMARA, 2015).

Embora, haja essa distinção o CPC/2015, em seu artigo 786, prevê como inadimplemento do devedor apenas o não cumprimento da obrigação, ipsis litteris:

Art. 786. A execução pode ser instaurada caso o devedor não satisfaça a obrigação certa, líquida e exigível consubstanciada em título executivo.

Dessa forma, o crédito certo e líquido torna-se exigível quando o devedor se torna inadimplente. No caso de execução por quantia certa, o exequente pode apresentar os cálculos 
atualizados até o dia da propositura da ação e caso constate erro no cálculo, o autor pode emendar a inicial (ABELHA, 2016).

\subsection{Responsabilidade patrimonial:}

A responsabilidade patrimonial do executado está prevista no capítulo $\mathrm{V}$, do título $\mathrm{I}$, do livro II, do CPC/2015, nesse sentido, infere-se que a regra geral no direito brasileiro é a responsabilidade patrimonial daquele que possui o dever de indenizar, excepcionalmente, o devedor da obrigação de pagar pensão alimentícia poderia ter sua liberdade cerceada, em virtude de expressa previsão constitucional. Ademais, Abelha (2016) destaca que em decorrência da assinatura do Pacto de San José da Costa Rica a prisão civil do depositário infiel foi derrogada, embora ainda haja disposição na Constituição da República Federativa do Brasil de 1988 (CRFB/88).

Por sua vez, Elpídio Donizetti (2016), leciona que há uma responsabilidade originária e outra secundária. A primeira forma de responsabilidade está prevista no artigo 789 do CPC/2015, a saber:

Art. 789. O devedor responde com todos os seus bens presentes e futuros para o cumprimento de suas obrigações, salvo as restrições estabelecidas em lei.

Destaca-se que a doutrina alemã tem separado os fenômenos do débito e da responsabilidade, ou seja, o devedor a que se refere o supracitado artigo possui o Schuld e o Haftung $^{3}$ já o devedor secundário, conforme leciona Donizetti (2016), possui apenas o Haftung (a obrigação de adimplemento). Além disso, no que tange a incidência desses institutos sobre o vínculo obrigacional é sabido que o segundo não existe sem o primeiro (ABELHA, 2016).

Igualmente, cumpre conceituar que:

A responsabilidade, já o disse Liebman (Processo de Execução, 1980, p. 30), é um vínculo de direito público processual, consistente na sujeição dos bens do devedor a serem destinados a satisfazer o credor que não recebeu a prestação devida, através da realização as sanção por parte do órgão judiciário. Daí decorre que o conteúdo normativo da responsabilidade patrimonial, como tratada no Código de Processo, não coincide, necessariamente, com a exigibilidade da obrigação nem está subordinado a regras de direito material. Responsabilidade patrimonial é tema de direito

\footnotetext{
${ }^{3}$ Schuld, também notório por débito ('debitum') é o dever legal de cumprimento de maneira espontânea. Na hipótese do débito não ser cumprido desta forma, surge a prerrogativa ao credor de interferir no patrimônio do devedor, trata-se do Haftung, sendo este encarregado pela obrigação/responsabilidade 'obligatio' (MEDINA, GOMES, 2012, p. 1)
} 
processual e como tal é tratada no Código. (GRECO FILHO, 2013. p. 73)

Por outro lado, o CPC/2015, no seu artigo 790, atribuiu a terceiros o Haftung, ou seja, o patrimônio dessas pessoas pode ser atingindo nas seguintes hipóteses:

Art. 790. São sujeitos à execução os bens: I - do sucessor a título singular, tratando-se de execução fundada em direito real ou obrigação reipersecutória; II - do sócio, nos termos da lei; III - do devedor, ainda que em poder de terceiros; IV - do cônjuge ou companheiro, nos casos em que seus bens próprios ou de sua meação respondem pela dívida; $\mathrm{V}$ - alienados ou gravados com ônus real em fraude à execução; VI - cuja alienação ou gravação com ônus real tenha sido anulada em razão do reconhecimento, em ação autônoma, de fraude contra credores; VII - do responsável, nos casos de desconsideração da personalidade jurídica.

Segundo Neves (2017), os cinco primeiros incisos previstos são a mera repetição os incisos do art. 592 do CPC/1973, tendo como novidade a inclusão do companheiro no inciso IV (defesa da meação). Embora, o inciso III esteja previsto como responsabilidade secundária, verifica-se que na verdade se trata de caso de responsabilidade primária. Além disso, constatase que os incisos VI e VII são uma inovação quanto a responsabilidade patrimonial secundária.

O regime de responsabilidade evoluiu, pois, da responsabilidade pessoal para patrimonial, de modo que, atualmente, a única forma de prisão cível admitida no ordenamento jurídico brasileiro é aquela em decorrência do inadimplemento da pensão alimentícia. A responsabilidade patrimonial também está presente em obrigações de dar, fazer e não fazer, ao quantificar o débito desta prestação a fim de satisfazer a pretensão do exequente. Portanto, “o executado responde apenas com o seu patrimônio presente e futuro, pelo cumprimento das suas obrigações" (MARINONI; ARENHART; MITIDIERO, 2016, p. 858) independente de com quem esteja o bem do executado.

\subsection{Técnicas de execução}

A técnica de execução consiste na averiguação de como a relação processual se formaliza, ou seja, versa sobre a observação se a tutela executiva se formaliza por meio de processo autônomo, ou não.

A execução de título extrajudicial, segundo Gonçalves (2016), se dá de forma imediata, citando o devedor para o cumprimento de sua obrigação, isto é, trata-se de um processo autônomo. Esse mesmo autor ressalva que embora a sentença arbitral, a estrangeira e a penal sejam consideradas títulos judiciais, a execução dessas se dá em um processo autônomo, 
notadamente porque no segundo e terceiro caso o juízo da execução é diferente do conhecimento.

Igualmente, a tutela executiva fundada em título judicial, via de regra, ocorre por meio da técnica de execução mediata, ou seja, a execução é uma fase do processo. Essa fase pode, então, ocorrer fundada em uma sentença definitiva, ou provisória (PINHO, 2017).

Por sua vez, tanto a tutela mediata quanto a imediata realizam atos executivos com o objetivo de satisfazer a pretensão do exequente. Estes atos também podem ser denominados de instrumentos sub-rogatórios e coercitivos, cujas características podem ser resumidas nos seguintes termos:

Por intermédio dos meios sub-rogatórios, o Estado-juiz substitui a atividade do executado, prescindindo da sua vontade, e realiza o direito do exequente. Podem ser divididos ainda em instrumentais e finais. São exemplos, respectivamente, a penhora de bens e a expropriação em leilão público (também os atos de desapossamento nas execuções de entrega de coisa). Os meios coercitivos são aqueles que não prescindem da vontade do executado, pois atuam diretamente sobre ela, com função coercitiva de pressão psicológica, como se fosse um estimulante positivo no cumprimento da obrigação inadimplida. Tais atos têm grande vantagem sobre os anteriores, pois permitem a atuação da norma concreta por ato do próprio executado, com menos custo e ônus tanto para o Estado quanto para o exequente. Tais medidas coercitivas devem ser direcionadas contra o executado, fazendo com que este raciocine no sentido de compreender que seria mais vantajoso cumprir e satisfazer o direito exequendo do que assumir a medida coercitiva que lhe foi imposta. São exemplos de medidas coercitivas as multas diárias, a prisão civil nas execuções de prestações alimentícias etc. (ABELHA, 2016, p. 36)

Considerando as alterações que esses atos executivos geram no mundo dos fatos, verifica-se que a finalidade dos meios coercitivos é compungir o devedor ao adimplemento da obrigação personalíssima. Por outro lado, diante de obrigações fungíveis o Estado se utiliza de instrumentos sub-rogatórios para satisfazer a pretensão do autor (ALVIM, ASSIS, 2016). Dessa forma, é possível inferir que saber utilizar adequadamente esses meios executivos é essencial para que a tutela executória seja efetiva.

\subsection{Espécies de execução}

A tutela executiva possui como requisitos essenciais a presenta de um título executivo que contenha uma obrigação certa, líquida e exigível, este último requisito, por sua vez, reside no inadimplemento do devedor. Para que esse processo seja frutífero, Abelha (2016) leciona que o magistrado dispõe de instrumentos coercitivos e sub-rogatórios previstos no CPC/2015. 
Dessa forma, as várias espécies de execução existem em conformidade com os tipos de obrigações existentes.

A execução para entrega de coisa está prevista no código processual do artigo 806 a 813, sendo utilizado para compungir o devedor a adimplir a obrigação de entregar coisa certa ou incerta (DONIZETTI, 2016).

Quando o devedor adota a postura de permanecer inerte, a lei autoriza o juiz fixar multa por período de atraso, e caso o título já tenha previsto essa multa, pode o juiz reduzi-lo caso entenda ser necessário. Aliás, verifica-se a possibilidade de conversão da obrigação de entregar coisa certa ou incerta em perdas e danos, isto é, diante do insucesso da entrega da coisa, essa é quantificada para que a execução de entregar coisa se transforme em execução por quantia certa (LOURENÇO, 2017; GONÇALVES, 2016).

Para tanto, é realizado um incidente de liquidação em que o magistrado arbitra o valor da coisa, com base em perícia realizada por profissional com conhecimento científico capaz de quantificar seu valor e simultaneamente, em autos apartados, liquidam-se as perdas e danos sofridos pelo exequente por artigo (ABELHA, 2016). Mas, se o exequente optar por uma liquidação sucessiva é possível que esta seja realizada nos mesmos autos.

A execução das obrigações de fazer, por sua vez, ao invés de possui como objeto da obrigação a coisa, ela possui o enfoque na pessoa que irá fazer ou não fazer algo. Assim, é preciso verificar se a prestação a ser realizada é fungível ou infungível, pois isto é um fator determinante para a escolha dos atos executivos a serem adotados (MONTENEGRO FILHO, 2016).

As obrigações de fazer fungíveis permitem que sejam adotados procedimentos subrogatórios e coercitivos para satisfazer a obrigação. Diferentemente, das obrigações infungíveis que não permitem que o magistrado utilize meios sub-rogatórios para satisfazer a obrigação (ABELHA, 2016).

Por outro lado, em se tratando de prestação negativa, é preciso ressalvar o seguinte entendimento: "a despeito de a liberdade negocial imperar especialmente no Direito das Obrigações, deve ser observado que não serão consideradas licitas as obrigações de não fazer que violem princípios de ordem pública e vulnerem garantias fundamentais" (GAGLIANO, PAMPLONA FILHO, 2016, p.101). Por fim, se a execução da obrigação de fazer for infrutífera é possível convertê-la em pecúnia por intermédio do incidente de liquidação e prosseguir realizando uma execução de quantia certa (GONÇALVES, 2016).

A execução por quantia certa é a espécie de execução adotada diante da obrigação de pagar quantia. É sabido que um dos princípios afetos a tutela executiva é que as execuções são 
específicas, ou seja, o exequente deve especificar qual espécie adotou. Entretanto, diante da impossibilidade de entregar a coisa, ou de adimplir a prestação de fazer, verifica-se que essas tutelas específicas se transformam em execução por quantia certa em decorrência da responsabilidade patrimonial do devedor (CÂMARA, 2015).

Em síntese, o "procedimento da execução por quantia certa, [...], desenvolve-se em quatro fases: a fase da proposição (ajuizamento), a da apreensão de bens (penhora, que pode ser antecedida por arresto), a da expropriação (leilão) e a do pagamento" (DONIZETTI, 2016, p. 1126).

\section{Da penhora}

É sabido que "a penhora é o ato de apreensão e depósito de bens para empregá-los, direta ou indiretamente, na satisfação do crédito executado " (DIDIER JÚNIOR; CUNHA; BRAGA; OLIVEIRA, 2017, p. 801). Segundo Theodoro Júnior (2017), a penhora é um processo de individualização do patrimônio do devedor que arcará com a satisfação do crédito, para tanto, o Estado primeiramente declara qual será o bem afetado para depois proceder a expropriação e adjudicação. Semelhantemente, é possível inferir que:

Já para Neves (2017), a penhora é o meio executivo, de caráter sub-rogatório, típico da execução por quantia certa, que individualiza um bem ou os bens do patrimônio do devedor com o escopo de satisfazer o crédito exequendo. Por conseguinte, a penhora produz os seguintes efeitos de ordem material e processual:

Os seus efeitos materiais são aqueles que se irradiam na esfera cível ou penal dos sujeitos do processo, a saber: a) alteração do título de posse do executado - desdobra-se a sua posse sobre o bem penhorado, com a transferência da posse direta para o depositário (que pode ser o próprio devedor) e a manutenção da posse indireta com o executado; b) a ineficácia dos atos de disposição (alienações/onerações para terceiros) do devedor para a execução; e a e) a criminalidade (art. 179, Código Penal) dos atos lesivos ao bem penhorado, que dificultem ou frustrem os resultados do feito executivo. Os efeitos processuais são aqueles que repercutem no contexto estritamente processual: a) a individualização de um bem do devedor, dentre todos, a ser expropriado judicialmente e sua consequente vinculação ao juízo executivo; b) a sua guarda e conservação pelo depositário, auxiliar do juízo, garantindo-se a futura satisfação do crédito; e) garantida a execução, abre-se a possibilidade de concessão de efeito suspensivo à defesa do executado; d) a preferência para o credor sobre bem penhorado, em detrimento dos demais credores sem privilégios ou garantias materiais. (DIDIER JÚNIOR; CUNHA; BRAGA; OLIVEIRA, 2017, p. 806). [grifo nosso] 
Considerando esses efeitos, é possível inferir que a penhora não retira de plano a propriedade dos bens, antes debilita os poderes de utilização dos bens apreendidos judicialmente para extinguir a propriedade com a expropriação final. Consequentemente, “esvaziam-se, assim, os poderes jurídico-materiais que definem o gozo direto da coisa, reduzindo-se o executado à situação de nu-proprietário, representada pela detenção de 'um simples poder jurídico de disposição do direito"” (THEODORO JÚNIOR, 2017, p. 563).

Dessa forma, somente pode "ser objeto de penhora os bens do patrimônio do devedor e do patrimônio de terceiros responsáveis (art. 790, CPC). Jamais deve ser atingido o patrimônio de terceiros estranhos à obrigação ou à responsabilidade originada do seu inadimplemento" (DIDIER JÚNIOR; CUNHA; BRAGA; OLIVEIRA, 2017, p. 810).

\subsection{Da ordem preferencial de penhora estabelecida no CPC/2015}

O CPC/2015 estabeleceu, em seu artigo 835, uma ordem preferencial para a realização da penhora, a saber:

Art. 835. A penhora observará, preferencialmente, a seguinte ordem: I dinheiro, em espécie ou em depósito ou aplicação em instituição financeira; II - títulos da dívida pública da União, dos Estados e do Distrito Federal com cotação em mercado; III - títulos e valores mobiliários com cotação em mercado; IV - veículos de via terrestre; V - bens imóveis; VI - bens móveis em geral; VII - semoventes; VIII - navios e aeronaves; IX - ações e quotas de sociedades simples e empresárias; $X$ - percentual do faturamento de empresa devedora; XI - pedras e metais preciosos; XII - direitos aquisitivos derivados de promessa de compra e venda e de alienação fiduciária em garantia; XIII - outros direitos.

Donizetti (2017), ao fazer uma análise comparativa desse dispositivo, constatou que houve uma: “(I) alteração da ordem dos bens passíveis de penhora; e (II) inclusão no rol dos bens penhoráveis dos semoventes (VII), das ações e quotas de sociedades simples (IX) e dos direitos aquisitivos derivados de promessa de compra e venda e de alienação fiduciária em garantia (XII)" (2017, p. 1.044). É possível afirmar que essa alteração decorra, justamente da discussão sobre quais medidas são mais comumente implementadas e, por conseguinte, seriam mais efetivas de um modo geral.

Importa destacar que, segundo Neves (2017), essa ordem preferencial pode ser mitigada a partir dos princípios do menor sacrifício patrimonial ao executado e da máxima efetividade, isso porque a própria redação da norma não estabelece algo peremptório, em que pese o parágrafo $1^{\circ}$ desse artigo estabelece a prioridade de penhora em dinheiro. 
Todavia, essa alteração da ordem legal não se pode basear em um simples argumento da parte exequente, pois o Superior Tribunal de Justiça, em sua jurisprudência, tem imputado ao exequente a responsabilidade de acostar nos autos os elementos que subsidiam a alteração da ordem legal. Esse entendimento pode ser constatado no seguinte julgado:

DIREITO PROCESSUAL CIVIL. AGRAVO INTERNO NO AGRAVO EM RECURSO ESPECIAL. EXECUÇÃO. NEGATIVA DE PRESTAÇÃO JURISDICIONAL. NÃO OCORRÊNCIA. PENHORA. ORDEM LEGAL. PECULIARIDADES DO CASO. PENHORA NO ROSTO DOS AUTOS. POSSIBILIDADE. REAVALIAÇÃO DO CONJUNTO FÁTICOPROBATÓRIO DOS AUTOS. INADMISSIBILIDADE. INCIDÊNCIA DA SÚMULA N. 7/STJ. INTERESSES. DEVEDOR E CREDOR. SÚMULA N. 83/STJ. DECISÃO MANTIDA. 1. Inexiste afronta ao art. 1.022 do CPC/2015 quando a Corte local pronunciou-se, de forma clara e suficiente, acerca das questões suscitadas nos autos, manifestando-se sobre todos os argumentos que, em tese, poderiam infirmar a conclusão adotada pelo Juízo. 2. O recurso especial não comporta o exame de questões que impliquem incursão no contexto fático-probatório dos autos, a teor do que dispõe a Súmula n. 7 do STJ. 3. No caso concreto, o Tribunal de origem analisou as provas dos autos para concluir que seria possível a penhora no rosto dos autos. Alterar esse entendimento demandaria o reexame de provas, inviável em recurso especial. 4. A jurisprudência do STJ é pacífica ao afirmar que "o princípio da menor onerosidade ao devedor deve estar em harmonia com o interesse do credor" (AgRg no AREsp n. 158.707/SP, Relator Ministro SIDNEI BENETI, TERCEIRA TURMA, julgado em 22/5/2012, DJe 5/6/2012). 5. Agravo interno a que se nega provimento. (BRASIL, Superior Tribunal de Justiça. Agravo de Instrumento no Agravo em Recurso Especial. AgInst no AREsp 1304591 PR 2018/0133951-0. Relator: Min. Antônio Carlos Ferreira. Órgão Julgador: Quarta Turma.2020)

Da análise desse julgado, é possível inferir que a mitigação da ordem legal da penhora se dá a partir da demonstração de circunstâncias fáticas que justificam o ato. Ademais, verifica-se que a rediscussão dos aspectos fáticos da alteração de ordem é de competência do Tribunal Regional Federal ou do Tribunal de Justiça.

Outrossim, é possível constatar nesse julgado a premissa de que, em tese, a ordem de penhora prevista nos incisos do artigo 835 do CPC/2015 observa o princípio do menor sacrifício patrimonial ao executado, de modo que as medidas progridem de constrições menos agressivas para mais agressivas ao patrimônio do devedor.

Assim sendo, a gradação legal da ordem de penhora progride, em tese, do meio menos oneroso ao mais oneroso pode ter sua ordem alterada ante a demonstração de a inversão da ordem do artigo 835 do CPC/2015 é menos oneroso ao executado ou há um ganho na eficiência e efetividade da execução (GONÇALVES, 2017). 


\section{Dos precatórios}

“O Precatório é uma despesa pública de natureza judicial, que, logo de início, não se pode programar quando ocorrerá, tampouco quanto deverá ser pago. Contudo, é possível prever a ocorrência dessa despesa anualmente" (CORREIA, SIMÕES, 2019, p. 24). Nesse sentido, Abraham (2017) ressalta que se houvesse a constrição patrimonial de recursos públicos a medida que ocorresse o trânsito em julgado dos processos em que a fazenda pública fosse sucumbente, isso implicaria um desequilíbrio orçamentário capaz de inviabilizar a ação da administração.

Dito de outro modo, entende-se que o precatório é "uma ordem de pagar, decorrente de decisão judicial transitada em julgado contra a Fazenda Pública, ou seja, é um valor no qual o ente público é devedor e está sendo executado" (QUEIROZ, 2017, p. 13). Esse procedimento está previsto no artigo 100 da CRFB/88, in verbis:

Art. 100. Os pagamentos devidos pelas Fazendas Públicas Federal, Estaduais, Distrital e Municipais, em virtude de sentença judiciária, far-se-ão exclusivamente na ordem cronológica de apresentação dos precatórios e à conta dos créditos respectivos, proibida a designação de casos ou de pessoas nas dotações orçamentárias e nos créditos adicionais abertos para este fim

Analisando esse dispositivo é possível inferir que esse procedimento é adotado para o pagamento de condenações em que a administração direta, autárquica e fundacional venha sofrer. Abraham (2017) destaca que não há consenso entre os autores sobre a possibilidade de pagamento por precatório de condenações contra empresas pública e sociedades de economia mista, em que pese o Supremo Tribunal Federal (STF) já tenha se pronunciado por essa possiblidade quando essas empresas desenvolverem atividades em regime de monopólio e sem concorrência com o particular.

Igualmente, a Corte Constitucional brasileira ${ }^{4}$ assentou o entendimento de que essa forma de pagamento decorre do princípio da impenhorabilidade dos bens públicos e da isonomia entre os credores do Estado, o qual é aplicável as pessoas jurídicas de direito público interno com exceção dos conselhos fiscalização, porquanto são custeados pelas anuidades dos profissionais ao invés de recursos públicos da União (RAMOS FILHO, 2017).

Outrossim, verifica-se que o Presidente do Tribunal responsável por esse pronunciamento judicial apresentará ao respectivo Chefe do Poder Executivo a ordem de pagamento, que será pago em ordem cronológica. Nessa senda, impende salientar que se trata

\footnotetext{
${ }^{4}$ BRASIL, Supremo Tribunal Federal, Suspensão de Segurança no Agravo Regimental (SS-AgR) 2961/MA, Relatora Min. Ellen Gracie, Pleno, 2008; BRASIL, Supremo Tribunal Federal, Recurso Extraordinário (RE) 938.837/SP, Relator: Min. Edson Fachin; Relator do Acórdão: Min. Marco Aurélio; Pleno, 2017
} 
de uma "garantia constitucional do cumprimento de decisão judicial contra a Fazenda, que se define em regras de natureza processual conducentes à efetividade da sentença condenatória transitada em julgado" (RAMOS FILHO, 2017, p. 215).

Lado outro, o ordenamento jurídico prevê que as decisões condenatórias de pagar quantia certa, cujo valor é considerado de menor vulto para a fazenda pública, devam ser pagas pelo sistema de Requisição de Pequeno Valor (RPV), já que esses credores não estão em mesma situação aos credores de precatórios. Nesse sentido, o parágrafo $3^{\circ}$ do artigo 100 da CRFB/88 estabelece o ônus dos entes federados em estabelecerem os valores máximos a serem pagos pelo sistema do RPV e os mínimos do precatório.

Ademais, importa salientar que a União, por meio da Lei Federal n. 10.259, de 12 de julho de 2001, estabeleceu o valor máximo de sessentas salários mínimos a serem pagos pelo primeiro regime, levando ainda em consideração a competência dos juizados especiais federais.

Caso o estado membro não tenha editado lei estabelecendo os valores máximos a serem pagos por RPV, aplica-se a regra prevista no artigo 87, inciso I, do Ato das Disposições Constitucionais Transitórias (ADCT), que estabelece o montante de quarenta saláriosmínimos para o regime de RPV dos Estados e para o Distrito Federal se houver o silêncio legislativo.

Assim, é possível inferir que o pagamento de RPVs distingue-se dos precatórios, pois aqueles são pagos diretamente aos credores, por meio de transferência bancária, enquanto os precatórios são inclusos me uma fila de credores e o seu efetivo pagamento é previsto nas Leis de Diretrizes Orçamentárias (LDO).

Inclusive, o parágrafo $5^{\mathrm{a}}$ do artigo 100 da CRFB/88 prevê que o Poder Executivo deve incluir na LDO para que haja o pagamento até o fim do exercício financeiro posterior ao da apresentação. Assim, "os precatórios possuem prazos para pagamento variando conforme a data em que forem apresentados ao Poder Executivo" (RODRIGUES, 2016, p. 144), em outras palavras:

Se o precatório for apresentado a partir do segundo dia do mês de julho do corrente ano (2019), então ele seria incluso no orçamento do ano subsequente (2020), estendendo o prazo para o pagamento para o ano de 2021, não incidindo juros de mora nesse lapso temporal, por força da Súmula Vinculante n. $17^{5}$ (CORREIA; SIMÕES, 2019, p. 25).

\footnotetext{
${ }^{5}$ Súmula Vinculante 17. Durante o período previsto no parágrafo $1^{\circ}$ do artigo 100 da Constituição, não incidem juros de mora sobre os precatórios que nele sejam pagos. (BRASIL, 2009, online)
} 
Sobre esse procedimento, Vantroba (2014) sustenta que "a execução judicial por meio do regime de precatórios é um privilégio dado à Fazenda Pública como consequência do princípio da supremacia do interesse público" (apud FERREIRA, 2017, p. 31), uma vez que estabelece uma fila de credores a serem pagos conforme a previsão orçamentária. Caso esses recursos findem

Inexiste a obrigação do Poder Executivo em solicitar a abertura de crédito adicional suplementar ou especial ${ }^{6}$ para sanar os precatórios, se não houver recursos correspondentes para a abertura desse crédito adicional, aplicandose a célebre Teoria da Reserva do Possível, na medida em que não seria de interesse público a criação de uma despesa pública capaz de gerar déficit orçamentário, sobretudo pelo fato do crédito suplementar integrar o orçamento. (CORREIA; SIMÕES, 2019, p. 26)

Segundo Martins (2013), o artigo 78 do ADCT estabeleceu uma espécie de "Calote Constitucional", pois foi dado extenso prazo de dez anos para que os Estados-membros paguem os seus créditos. Nessa linha de ideias, De Mello (2016) destaca que o pagamento desses créditos deve observar a Lei de Responsabilidade Fiscal, isto é, observar o cumprimento das metas ali estabelecidas.

No caso de não pagamento dos precatórios ou sua mora, Eros Graus, ressalva que "nessas hipóteses, cabe à Administração Pública demonstrar perante o órgão judiciário competente a impossibilidade de cumprir a decisão judicial" (apud HARADA, 2017, p.41), sob pena se haver a responsabilidade do gestor público ou a adoção de medidas executivas.

Por fim, importa destacar que a demora e o inadimplemento de precatórios é uma questão que não envolve apenas questões arrecadatória, mas, principalmente, de alocação de recurso e planejamento para redução da dívida do Estado (MARTINS, 2013; FERREIRA, 2017). Nessa linha de ideias, “devem ser avaliadas propostas de estabelecimento de aporte mínimo que garantam o pagamento do montante acumulado, e não como o observado na prática, em que os índices estabelecidos mal acompanham o crescimento da dívida" (SANTANNA; ALVES, 2016, p. 15).

\subsection{Análise de como é possível realizar a penhora de créditos de precatórios}

É sabido que a penhora no rosto dos autos é realizada com fundamento no inciso XIII do artigo 835 do $\mathrm{CPC} / 2015$, isto é, "recai sobre eventual direito do executado, discutido em

\footnotetext{
${ }^{6}$ Os créditos adicionais são os valores concedidos para suprir a falta de recursos orçamentários. Segundo o art. 40 da Lei $\mathrm{n}^{\circ}$ 4.320/1964, os créditos adicionais são as autorizações de despesa não computadas ou insuficientemente dotadas na Lei de Orçamento. Registre-se que o ato que abrir crédito adicional deverá indicar
} 
processo judicial. [...]. Caso ele saia vitorioso, a penhora terá por objeto os bens ou créditos que lhe forem reconhecidos ou adjudicados" (GONÇALVES, 2017, p. 988). Mas na hipótese de improcedência da ação a penhora realizada torna sem efeito.

No caso processos movidos contra a fazenda pública, o pagamento do direito do executado se dará ou pelo rito do Requerimento de Pequeno Valor ou por meio da requisição de precatórios, por conseguinte, a penhora se dará observando esses procedimentos. Nesse sentido, a Resolução do CNJ n. 303/2019, estabelece, em seu artigo 37, que o juízo interessado na penhora encaminhará ao responsável por elaborar ofício precatório a ordem de penhora.

Essa disposição evidencia que o Presidente do Tribunal atuará administrativamente no registro desse ato judicial (art. $3^{\circ}$, III, dessa Resolução). A vista disso, o artigo 38 dessa Resolução estabelece o seguinte procedimento:

Art. 38. Tendo sido apresentado o ofício precatório ao tribunal, o juízo da execução comunicará o deferimento da penhora do crédito para que sejam adotadas as providências relativas ao respectivo registro junto ao precatório.

Nessa linha de ideias, importa destacar que o procedimento descrito nessa resolução está em consonância com o artigo 860 do CPC/2015, que diz:

Art. 860. Quando o direito estiver sendo pleiteado em juízo, a penhora que recair sobre ele será averbada, com destaque, nos autos pertinentes ao direito e na ação correspondente à penhora, a fim de que esta seja efetivada nos bens que forem adjudicados ou que vierem a caber ao executado.

Analisando o supracitado dispositivo é possível inferir que "objeto da penhora é o direito patrimonial litigioso, de natureza pessoal ou real, cuja titularidade é atribuída ao executado, o qual, no processo em que será realizada a penhora“ (DONIZETTI, 2017, p. 1071). Por conseguinte, o exequente sub-rogará o executado no seu crédito contra a fazenda pública, para tanto, o artigo 39 dessa Resolução aplica o conjunto de regras e procedimentos da cessão de créditos ao ser deferida a penhora.

O artigo 42 dessa Resolução procedimentalizou que para a cessão de créditos de fato ocorrer se faz necessário averbar os documentos frutos desse negócio jurídico junto a Presidência do Tribunal para que surtam os efeitos jurídicos, notadamente quanto ao direito do cessionário em receber o crédito com a Fazenda Pública. Nesse sentido, importa conceituar que:

A cessão de créditos oriundos de precatório constitui um direito subjetivo do credor da Fazenda Pública em ser substituído por um terceiro. Neste ato, o

a importância, sua espécie e a classificação da despesa, até onde for possível (art. 46, Lei no 4.320/1964), e, em regra, terá vigência adstrita ao exercício financeiro em que foram abertos. (ABRAHAM, 2017, p. 312) 
cessionário assume a posição do credor originário, sem, no entanto, alterar a ordem de pagamento nem possibilitar a expedição de RPV, no caso de cessão parcial do crédito (CORREIA; SIMÕES, 2019, p. 31)

Nessa senda, importa destacar que o resultado da averbação do negócio jurídico é inscrever no nome do cessionário parcial junto com o cedente ou no caso da cessão total a cadeia se substituição do direito de perceber o crédito. Ademais, ressalva-se que o artigo 43 da Resolução do CNJ n. 303/2019 prevê a hipótese de emissão de precatório superpreferencial ao beneficiário (original ou cessionário), que preencher os pressupostos do parágrafo $2^{\circ}$ do artigo 100 da CRFB/88, para que esse receba o valor correspondente.

Considerando esses aspectos do procedimento da cessão de precatório a serem observados no ato da penhora, destaca-se a averbação da cadeia de beneficiários do crédito. Por fim, importa ressalvar que o artigo 40 dessa Resolução limita a penhora ao crédito disponível do precatório, a saber:

Art. 40. A penhora somente incidirá sobre o valor disponível do precatório, considerado este como o valor líquido ainda não disponibilizado ao beneficiário, após incidência de imposto de renda, contribuição social, contribuição para o FGTS, honorários advocatícios contratuais, cessão registrada, compensação parcial e penhora anterior, se houver.

Ainda, salienta-se que no momento da Etapa Financeira, em que há o empenho financeiro, liquidação e pagamento (FERREIRA, 2017), os valores penhorados são postos a disposição do juízo que determinou a penhora, consoante estabelece o artigo 41 da Resolução do CNJ n. 303/2019, a saber:

Art. 41. Quando do pagamento, os valores penhorados serão colocados à disposição do juízo da execução para repasse ao juízo interessado na penhora, não optando o tribunal pelo repasse direto.

Analisando o supracitado dispositivo, após o pagamento do crédito do precatório, o crédito penhorado será posto a disposição do juízo, para que este realize o procedimento de pagamento ao credor, extinguindo, assim, a respectiva execução se houver a satisfação do crédito.

\section{Considerações finais}

O presente artigo versa sobre a análise de como é possível realizar a penhora de créditos de precatório. Destaca-se, para tanto, que o CPC/2015 estabeleceu o pressuposto processual de existência de um título executivo judicial ou extrajudicial certificador de um direito para que seja movida qualquer execução. Consequentemente, o Estado Juiz adotará uma série de providências sub-rogatórias e coercitivas para ver satisfeita a obrigação objeto do litígio. 
Por conseguinte, é possível afirmar que a penhora é o procedimento essencial para a satisfação da obrigação de pagar quantia certa. Dentre a ordem legal de penhora, verifica-se a possibilidade de penhora de créditos de precatório é uma forma de penhora no rosto dos autos, com fundamento no inciso XIII do artigo 835 do CPC/2015, de modo que é uma via excepcional de constrição patrimonial.

Em relação ao pagamento de precatórios, importa salientar que este sistema é a forma de pagamento das condenações contra a fazenda pública, em razão da predominância do interesse público sobre o privado, bem como na necessidade de a administração pública planejar o pagamento de tais despesas. Atualmente, os precatórios têm sido regulados pela Resolução do CNJ n. 303, de 18 de dezembro de 2019.

Nesse diapasão, caso o credor de um precatório esteja sendo executado judicialmente o exequente deste poderá requerer a penhora deste crédito com o Estado. Logo, a ordem de penhora será encaminhada para o juízo que requisitou o precatório e posteriormente será averbada essa determinação no procedimento junto à Presidência do Tribunal para que o devedor tenha ciência de que o crédito disponível será constrito.

Verificou-se também o resultado de que o cumprimento da decisão de penhora depende da disponibilidade do crédito no precatório, pois o executado pode ter realizado uma cessão de crédito anterior a penhora, bem como a existência de destacamento de honorários advocatícios e a incidência de tributos.

No transcorrer da pesquisa, verificou-se que o art. 43 dessa Resolução estabelece a hipótese de emissão de precatório superpreferencial aquele que preenche as hipóteses do art. $100, \S 2^{\circ}$, da CRFB/88, em razão disso, levantou-se o questionamento se o ato da penhora pode gerar o mesmo benefício ao titular do crédito que substituirá o credor da Fazenda Pública, pois esse benefício é dado na hipótese de cessão.

Igualmente, levantou-se o questionamento sobre a possibilidade de penhora sobre o direito do cessionário em receber o precatório, já que no processo que instrumentaliza essa execução registra a cadeia domínio desse direito. Por fim, indagam-se o limite da aplicabilidade das disposições da cessão de precatório no procedimento de penhora, segundo da Resolução do CNJ n. $303 / 2019$.

\section{Referências}

ABELHA, Marcelo. Manual de execução civil. - 6. ${ }^{\text {a }}$ ed. rev. e atual. - Rio de Janeiro: Forense, 2016. 
ABRAHAM, Marcus. Curso de direito financeiro brasileiro. - 4. ed. rev. atual. e ampl. Rio de Janeiro: Forense, 2017.

ALVIM, Angélica Arruda (Coord.); ASSIS, Araken de; MACIEL, Daniel Baggio; et al.

Comentários ao código de processo civil- São Paulo: Saraiva, 2016.

BRASIL, Constituição da República Federativa do Brasil de 1988 (CRFB/88).

Promulgada em 5 de outubro de 1988. Disponível

em:<http://www.planalto.gov.br/ccivil_03/constituicao/constituicao.htm>. Acesso em: 26 de janeiro de 2018.

BRASIL, Conselho Nacional de Justiça. Resolução n. 303, de 18 de dezembro de 2019. DJe/CNJ $\quad n^{\circ}$ 263/2019, em 19/12/2019, p. 21-37. Disponível em: <https://atos.cnj.jus.br/atos/detalhar/3130>. Acesso em: 05 de setembro de 2020.

BRASIL, Lei n.13.105, de 16 de março de 2015. Diário Oficial da União de 17 de março de 2015. Disponível em: <https://www.planalto.gov.br/ccivil_03/_ato2015-

2018/2015/lei/113105.htm> Acesso em: 27 de dezembro de 2016.

BRASIL, Lei n. 5.869, de 11 de janeiro de 1973. Revogado pela Lei n.13.105, de 16 de março de 2015.2 Disponível em:

http://www.planalto.gov.br/ccivil_03/LEIS/L5869impressao.htm >. Acesso em 16 de outubro de 2020

BRASIL, Superior Tribunal de Justiça. Agravo de Instrumento no Agravo em Recurso Especial. AgInst no AREsp 1304591 PR 2018/0133951-0. Relator: Min. Antônio Carlos Ferreira. Órgão Julgador: Quarta Turma. Julgamento em: 18 de fevereiro de 2020.

Publicação: Dje 02.03.2020. Disponível em :

$<$ https://ww2.stj.jus.br/processo/revista/documento/mediado/?componente=ITA\&sequencial= $1913650 \&$ num_registro $=201801339510 \&$ data $=20200302 \&$ formato=PDF $>$. Acesso em: 26 de setembro de 2020.

BRASIL, Supremo Tribunal Federal. Súmula Vinculante 17. DJE de 10-11-2009. Disponível em: <http://www.stf.jus.br/portal/jurisprudencia/menuSumario.asp?sumula=1241>. Acesso em: 28 de agosto de 2020.

BUENO, Cassio Scarpinella. Novo Código de Processo Civil anotado [livro eletrônico]. - 3. ed. - São Paulo: Saraiva, 2017.

CÂMARA, Alexandre Freitas O novo processo civil brasileiro [livro eletrônico] - São Paulo: Atlas, 2015.

CORREIA, Álisson Barbalho Marangôni; SIMÕES, Pedro Henrique Moreira. Análise dos critérios para a compensação de débitos inscritos na dívida ativa do estado de rondônia com 
créditos de precatório a luz da Lei 4.200/2017 e do Decreto 23.259/2018. In: Revista Guaporé, Associação dos Procuradores do Estado de Rondônia, p. 23-34, 2019.

DE MELLO, Marco Aurélio de Farias. A eficácia dos precatórios. THEMIS: Revista da Esmec, v. 1, n. 1, p. 181-184, 2016.

DIDIER JÚNIOR, Fredie; CUNHA, Leonardo Carneiro da; BRAGA, Paula Sarno; OLIVEIRA, Rafael Alexandria de. Curso de direito processual civil: execução. - 7. ed. rev., ampl. e atual. - Salvador: Ed. JusPodivm, 2017.

DONIZETTI, Elpídio. Incidente de desconsideração da personalidade Jurídica (arts. 133 a 137). In: GENJURÍDICO, [S.I.], 22 jun. 2016. Disponível em:

<http://genjuridico.com.br/2016/06/22/incidente-de-desconsideracao-da-personalidadejuridica-arts-133-a-137/>. Acesso em: 27 de dezembro de 2016.

Curso didático de direito processual civil. - 19. ed. revisada e completamente reformulada conforme o Novo CPC - Lei 13.105, de 16 de março de 2015 e atualizada de acordo com a Lei 13.256, de 04 de fevereiro de 2016. - São Paulo: Atlas, 2016.

Novo Código de Processo Civil comentado - 2. ed. rev., atual. eampl. - São Paulo: Atlas, 2017.

FERREIRA, Daniel Augusto Celestino. Análise dos determinantes de desempenho da gestão de precatórios e requisições de pequeno valor no âmbito do Tribunal de Justiça do RN. Natal, 2017.56f. Dissertação (Mestrado em Ciências Contábeis) Universidade Federal do Rio Grande do Norte. Orientação Prof. Dr. Erivan Ferreira Borges, Programa de Pósgraduação em Ciências Contábeis.

GAGLIANO, Pablo Stolze; PAMPLONA FILHO, Rodolfo. Novo curso de direito civil, volume 2: obrigações. - 17. ed. rev., ampl. e atual. de acordo com o novo CPC. - São Paulo: Saraiva, 2016.

GONÇALVES, Marcus Vinicius Rios Novo curso de direito processual civil, processos nos tribunais e meios de impugnação das decisões: volume 3-9. ed. de acordo com o Novo Código de Processo Civil - Lei n. 13.105, de 16-3-2015 - São Paulo : Saraiva, 2016. . Direito processual civil esquematizado [livro eletrônico]. - 8. ed. - São Paulo: Saraiva, 2017.

GRECO FILHO, Vicente. Direito processual civil brasileiro, volume 3: (processo de execução a procedimentos especiais). - 22. Ed.- São Paulo: Saraiva, 2013.

HARADA, Kiyoshi. Direito financeiro e tributário. [livro eletrônico] - 26. ed. rev., atual. e ampl. - São Paulo: Atlas, 2017. 
LOURENÇO, Haroldo. Processo civil: sistematizado [livro eletrônico]. - 3. ed. rev. e atual. Rio de Janeiro: Forense; São Paulo: MÉTODO, 2017.

MARINONI, Luiz Guilherme; ARENHART, Sérgio Cruz, MITIDIERO, Daniel. Novo

Código de Processo Civil comentado. -2. ed. rev., atual. e ampl.- São Paulo: Revista dos Tribunais, 2016.

Código de Processo Civil comentado. -3. ed. rev., atual. e ampl.- São Paulo: Revista dos Tribunais, 2017.

MARTINS, Ives Gandra da Silva [et al]. Tratado de direito financeiro, volume 1. [livro eletrônico] - São Paulo: Saraiva, 2013.

MEDINA, José Miguel Garcia. Direito processual civil moderno [livro eletrônico]. - 3.ed.-

São Paulo: Editora Revista dos Tribunais, 2017.

MEDINA, Mariana Bordinassi; GOMES, Francisco José Dias. A OBRIGAÇÃO COMO

DÉBITO E RESPONSABILIDADE (SCHULD e HAFTUNG)-RELAÇÃO COMPLEXA.

ETIC-ENCONTRO DE INICIAÇÃO CIENTÍFICA-ISSN 21-76-8498, v. 8, n. 8, 2012.

MONTENEGRO FILHO, Misael. Manual da advocacia cível: como advogar com o Novo

Código de Processo Civil [livro eletrônico]. - 3. ed. rev. e atual. - São Paulo: Atlas, 2016

NEVES, Daniel Amorim Assumpção. Manual de direito processual civil - Volume único.

[livro eletrônico]. - 9. Ed. - Salvador: Ed. JusPodivm, 2017.

PINHO, Humberto Dalla Bernardina de. Direito processual civil contemporâneo: processo de conhecimento, procedimentos especiais, processo de execução, processo nos tribunais e disposições finais e transitórias, volume 2 [livro eletrônico]. - 4. ed. - São Paulo: Saraiva, 2017.

QUEIROZ, Desiré Velasque. Antecipação em precatório: O Direito do Deficiente Físico Antecipar-Emenda Constitucional $\mathrm{n}^{\circ} 94$ de dezembro de 2016. Artigo Científico (Bacharelado). - Orientação Prof. Francisco Júnior Ferreira da Silva, Coordenação de Direito. Porto Velho: Centro Universitário São Lucas, 2017. 26p. Disponível em: < http://hdl.handle.net/123456789/2072>. Acesso em: 03 de abril de 2018.

RAMOS FILHO, Carlos Alberto de Moraes; LENZA, Pedro (Coord). Direito Financeiro. - 2 ed. - São Paulo: Saraiva, 2017.

RODRIGUES, Marco Antônio. A Fazenda Pública no Processo Civil, 2.ed. rev., atual. e ampl. São Paulo: Atlas, 2016.

SANTANNA, G.; ALVES, R. O regime de precatórios e o (des)interesse (público) no seu pagamento. Revista Digital de Direito Administrativo, v. 3, n. 1, p. 217-234, 11 jan. 2016. 
SEIFERT, Priscila Leal. O NOVO CPC E A RECOMPOSIÇÃO DO ERÁRIO: por uma tutela executiva mais efetiva. Publicações da Escola da AGU, v. 8, n. 3, 2016.

TARTUCE, Flávio. Direito civil, v. 2 : direito das obrigações e responsabilidade civil; 11. ed. rev., atual. eampl. - Rio de Janeiro: Forense; São Paulo: Método, 2016.

O Novo CPC e o Direito Civil. - 2. ed. rev., atual. eampl. - Rio de Janeiro:

Forense; São Paulo: Método, 2016.

THEODORO JÚNIOR, Humberto. Curso de Direito Processual Civil - vol. III. 50. ed. rev., atual. e ampl. - Rio de Janeiro: Forense, 2017. 